\title{
Global standards, global governance and the organization of global value chains
}

\author{
Khalid Nadvi*
}

\begin{abstract}
Compliance with international standards is now a sine qua non for entry into globalized production networks. Developing country firms and farms are confronted by an array of distinct product and process standards that they must meet. This has heightened the competitive challenges they face. Non-compliance can result in exclusion from profitable markets. This article uses the recent case of Nike's termination of sourcing of soccer balls from its lead supplier in Pakistan as a lens to analyse the relationship between standards and governance. The article addresses first the global governance implications associated with how standards are being shaped and implemented. Second, it considers how global standards affect the governance of value chain ties. Finally, in terms of questions for further research, it suggests the need to explore the relationship between standards and 'intra-firm' governance, in particular to assess outcomes for those engaged within the chains-namely local firms and their workers, and the social contexts in which global standards are imposed from the outside.
\end{abstract}

Keywords: international standards, labour standards, child labour, global value chains, governance, Pakistan

JEL classifications: F23, J80, L23, L50, O19

Date submitted: 14 December 2007 Date accepted: 29 January 2008

\section{Introduction}

In November 2006, the world's leading merchandiser of sports goods and one of the best recognized global brands, Nike, terminated its sourcing of soccer balls from the sports goods manufacturing cluster of Sialkot in Pakistan (Christian Science Monitor, 22 December 2006, accessed online http://www.csmonitor.com/2006/1222/p01s03wosc.html). The grounds for Nike's exit were the alleged presence of child workers in the supply chain organized and managed by its Sialkot supplier. ${ }^{1}$ The Nike 'pull-out' threw into sharp light the continuing challenges that developing country producers face in terms of compliance with international standards, and the consequences that this can have for the structure and organization of global value chains (GVCs). ${ }^{2}$ Nike's action

*Senior Lecturer in Development Economics, Institute of Development Policy and Management (IDPM), School of Environment and Development (SED), University of Manchester, Arthur Lewis Building, Oxford Road, Manchester, M13 9PL, UK. email<khalid.nadvi@manchester.ac.uk>

1 Nike re-entered the Sialkot cluster in May 2007 albeit sourcing from a different local supplier.

2 There has been much debate on the appropriate terminology, and the nature of similarities and distinctions between the concepts of global production networks, GVCs, commodity chains and filières. See Bair (2005), Hess and Yeung (2006), Coe and Hess (2007) and Coe et al. (2008) for a review of these distinctions. This article, while acknowledging the importance of the distinctions, relative strengths and gaps in each concept, uses in large measure the concept of GVCs. 
was in spite of an extensive and independent labour monitoring mechanism that had been in place in Sialkot since 1997 supported by the International Labour Organization (ILO) as well as other national and international agencies. In a previous study, I argued that the Sialkot sporting goods cluster's response to the child labour issue suggested the real prospect that addressing child labour could lead to wider developmental outcomes (Nadvi, 2004). The response, which sought to tackle the causes of child labour, involved a complex multi-stakeholder network initiative bringing together local, national and international actors from business, labour, non-governmental organizations (NGOs), the state, donors and international bodies. The 2006 Nike pull-out challenges that earlier conclusion, and highlights the need to revisit the agenda on the relationship between global standards and their impacts on GVCs.

This article addresses the subject of global standards and their relationship to debates on governance. Governance, put very simply, is the framework and institutional structures by which rules (which include laws at one extreme and norms at the other) are set and implemented. This can take various forms. Gereffi and Mayer (2006) distinguish between 'market', 'corporate' and 'industrial' governance. Market governance refers to the institutional frameworks whereby markets operate, through which contracts are enforced, markets are regulated and distributive outcomes brought about. Corporate governance addresses the firm's accountability to its various stakeholdersshareholders, employees and the community in which it is located; while industrial governance is concerned with the organization of ties between various actors engaged in a global supply chain (Gereffi and Mayer, 2006, p. 41). Coe and Hess (2007) provide another useful typology of differing forms of governance. They differentiate between 'institutional and political' governance, namely the national and international arenas where rules that shape market governance are framed; 'inter-firm' governance, which is akin to 'industrial' governance; and 'intra-firm' governance which addresses firm organization and in particular the relationship between capital and labour within the firm.

Debates on governance have been at the heart of much of the literature on globalization and GVCs (see, for example, Held and McGrew, 2002; Henderson et al., 2002; Dicken, 2003; Gereffi, 2005; Gereffi et al., 2005; Coe et al., 2008). Globalization has resulted in an extensive distribution of global production, which requires more intensive organization of ties within global production networks ('industrial' governance, 'inter-firm' governance or 'value chain' governance). It has also been associated with the relative decline of national regulatory governance, and the growing significance of both international and private actors in the arenas associated with 'market' and 'institutional and political' governance. Global standards are at the core of this process. They point to an intersection between inter-firm or value chain governance and market or institutional and political governance (Nadvi and Wältring, 2004). They also underline what Gereffi and Mayer (2006) refer to as the societal responses to the 'governance deficits' of the 1980s whereby private actors (business, NGOs, labour organizations) play a more significant role in defining many of the 'rules' through which global production networks are organized. ${ }^{3}$

3 This is not dissimilar to the Ponte and Gibbon (2005) argument that conventions relating to "civic content' - such as on issues of labour and environmental standards - shape the organization of particular types of GVCs. 
In light of this, this article raises questions on how standards effect 'inter-firm' and 'institutional and political' governance. First, it asks how standards shape the nature of what this article refers to as 'global governance'. Second, it assesses how standards impact on the governance of value chain ties. Does the imposition of standards make such relationships 'closer', potentially facilitating greater interaction between chain leaders and local suppliers, interaction that could accelerate processes of upgrading and even innovation within the chain? Or, does compliance with standards result in more arms length relationships within chains? The article also, in terms of questions for further research, suggests the need to consider the relationship between standards and 'intra-firm' governance, in particular the need to consider outcomes for those engaged within the chains - that is outcomes for local firms and their workers from global standards.

The article is structured as follows. The next section reviews the key themes emerging on the continuing development of global standards and their relationship with global governance. Section 3 focuses on the link between standards and the governance of GVC ties. Section 4 returns to the case study that this article started with - namely child labour and the Sialkot sports goods cluster. The brief analysis of this case study seeks to explore further how governance ties at both levels were influenced by the implementation of child labour standards. And, it considers what the recent challenge from 2006 suggests about these aspects of governance. Section 5 concludes and raises questions for further research. This focuses, in particular, on 'intra-firm governance' and the outcomes from the implementation of standards.

\section{Global standards and global governance}

Standards are commonly accepted benchmarks that transmit information to customers and end-users about a product's technical specifications, its compliance with health and safety criteria or the processes by which it has been produced and sourced. Thus, standards are important to promoting economic efficiency as they provide a basis for reducing information related transaction costs (David, 1995). In addition, standards can extend to customers and end users a basis for attaching credence, or value, to particular claims made about a product's characteristics and specification or the ways in which it has been produced. Reardon et al. (2001) describe standards as 'credence goods' whereby consumers can accept on face value the information supplied by a standard or a label (say, for example, on organic food products ${ }^{4}$ ) as the basis for making consumption decisions without needing to directly acquire this information through the supply chain.

There has been an extensive literature to date on the rise of global standards, ${ }^{5}$ on the array of distinct public and private, local and global actors engaged in the formulation of standards and, on the ways in which standards have become central to debates on the structure and organization of GVCs (Messner, 1997, 2004; Clapp, 1998, 2005; Finger and Tamiotti, 1999; O'Riordan, 2000; O'Rourke, 2003; Nadvi and Wältring, 2004; Zadek, 2004; Gereffi et al., 2005; Hughes, 2005, 2006; Ponte and Gibbon, 2005;

4 For a more detailed discussion on organic food standards see Gibbon and Memedovic (2006).

5 Locke et al. (2007) cite a 2003 World Bank study that indicates over 10,000 different standards and codes facing developing country producers with significant costs associated with compliance. 
Barrientos and Smith, 2007). The vast bulk of the literature has emphasized the international drivers behind the rapid proliferation of standards. However, as Kennedy (1999) and Lund-Thomsen (2007) note, national regulatory pressures can also be a driver to the implementation of standards within national and GVCs.

Standards take many shapes. They include company specific codes of conduct, sector specific standards and labels, as well as generic international standards that apply to product specifications, safety concerns, as well as to issues of process organization covering social, environmental and ethical concerns. In earlier work with Frank Wältring, I outlined a typology of global standards - distinguishing between product and process standards, between codes of conducts and labels and between distinct types of process standards - environmental, quality assurance, social and labour standards (Nadvi and Wältring, 2004). As argued in that study, the key policy challenges around the debate on global standards centred on the questions of who sets standards, who monitors standards, what are the costs of non-compliance and what are the governance implications?

What is increasingly apparent, however, is that as the number and range of standards have grown, so to have the complexity of issues, and policy challenges, associated with them. This makes it more difficult to focus on standards as a whole. The ways in which labour and social standards on the one hand and quality standards on the other hand have evolved point to differing policy challenges on standard setting, monitoring and the risks of non-compliance. Some types of standards have also tended to be relatively neglected within the literature. As Coe and Hess (2007) observe one particular gap has been discussion on product and technical standards. Product standards include specific designs, technical characteristics and attributes of a given product, as well as sector specific technical standards and product safety standards. Such standards are of critical importance, especially to well functioning global production networks without which globally dispersed supply chains could not function. They are also key to the issue of technical innovation in product design (Hawkins et al., 1995; Sturgeon, 2003; Hess and Coe, 2006). Another gap relates to the ways in which standards impact on actors, especially workers but also small-scale entrepreneurs, further down the production and supply chain. Recent studies by Barrientos and Smith (2007) on the poverty and social impact of the UK's Ethical Trading Initiative (ETI), and by Locke and Romis (2007) and Locke et al. (2007) on Nike's global supply chains, provide some evidence on outcomes for workers and local producers, but questions remain. In the discussion that follows, I outline briefly how process standards have continued to evolve, and the ways in which this affects aspects of global governance.

\subsection{Standards and their dynamic trajectories}

With globalization, heightened international competition and the emergence of complex ties between globally dispersed suppliers and global lead firms organized through distinct types of GVCs, standards have become critical in four key areas of policy debates. First, they can promote greater efficiency in an ever-more interconnected global economy. Second, they can help focus attention on social and environmental concerns. Third, they can provide a basis for new marketing niches, thus fostering new areas of competition. Fourth, they reflect new forms of global and regional governance that can both strengthen and challenge the regulatory domains of nation states. 
There are not only a growing number of standards covering an array of issues but also various bodies engaged in formulating standards. These include: national standards setting agencies, international sector specific bodies, the International Standards Organization (ISO) which brings together most national standards setting agencies, national regulators, regional regulators (such as the European Union) and international agencies (for example the ILO in the formulation of international labour standards). In addition to these national and global public sector agencies, various private actors - both not-for-profit non-governmental organizations (NGOs), many of which are international in scope, as well as private companies and transnational corporations (TNCs) - have also become important drivers in the standards setting agenda, especially on a range of process concerns.

The rapid growth in numbers of standards over the past two decades, the diverse scope that distinct standards address and the array of actors engaged in the process of setting and monitoring standards can lead to a sense of confusion on the subject. To provide some clarity to the discussion, Nadvi and Wältring (2004) put forward a typology of standards that distinguished between different fields of application of standards, different forms of standards, distinct levels of coverage of standards (both sectoral and geographical), different key drivers behind the standards, different processes of certification and different forms of regulatory impacts.

The typology was useful in highlighting how leading international standards worked, in which areas (sectors, regions) they were especially significant, which actors drove their formulation, as well as how they were monitored and implemented. The typology also threw light on the trajectories that particular types of standards: quality assurance, environmental and labour and social standards, had taken and were likely to take over time. This dynamic perspective suggested that in some areas there were tendencies towards convergence and harmonization in rule setting with the development of 'common' standards, whereas in others there was evidence of growing divergence.

Convergence was most apparent in quality assurance with the dominance of the ISO 9000 series of quality management standards. This is the most popular of global standards with currently close to a million ISO 9001:2000 certificates being issued worldwide (www.iso.org). Its centrality to the better functioning of global supply chains can be gauged by the fact that the highest levels of ISO 9001:2000 certifications are to be found in China, with over 140,000 certificates issued by the end of 2005 (ISO 2007). Convergence in the area of quality assurance standards around ISO 9000 has been accelerated by the manner in which the standard is independently verified by third parties - namely audit and compliance agencies. This makes the standard acceptable to users further up the value chain, and provides a degree of reassurance that suppliers conform to norms on quality management. ${ }^{6}$ However, in sectors marked by increasing technical complexity in knowledge-based transactions within the supply chain, the generic ISO 9000 standard was often seen as being an insufficient basis for quality assurance. Here, in more complex sectors, and in some cases individual firms, more refined and specialized quality management standards had begun to emerge. ${ }^{7}$

6 Nadvi (2004) and Seddon (2000) have, however, pointed to questions on the veracity of ISO 9000 certification, underlining the weaknesses in global and national regulation of standards certification bodies.

7 See Quadros 2004, for example, on quality management standards in the auto sector. 
In the area of environmental and labour standards there had been greater diversity from the outset, with an abundance of distinct company codes and labels. Yet, given the continuing vulnerability of branded lead firms to challenges of non-compliance within their dispersed supply chains, and the growing costs associated with dealing with a multitude of standards, there have been attempts towards greater harmonization on standards. Examples of such convergence include measures such as the ISO 14001 standard for environmental management, or the UK's ETI Base Code, which became the core framework on labour and ethical standards adopted by most of the UK's branded food and garment retailers who joined the ETI initiative, and the SA8000 standard that addresses labour issues. Similarly, the UN's voluntary initiative on the Global Compact is another example of seeking to promote convergence by bringing private companies on board to voluntarily agree to respect and promote 10 principles on human rights, labour, environment and anti-corruption within their supply chains. ${ }^{8}$

As is apparent from the earlier typology, and reinforced by recent experience, the agenda of international standards continues to evolve. Thus, the most recent element of the ISO 14000 series of environmental management systems standards is the ISO 14064 standard, issued in 2006, on greenhouse gas verification and accounting, which seeks to take on board new challenges for industry on greenhouse emissions. Similarly, the ISO 28000 standard, published in 2007, addresses concerns on security within the supply chain, including assessment of measures to avert risks of piracy and terrorism. In the area of social responsibility, there is the ISO 26000 series - which will be published as a set of guidelines in late 2008 and is due to be released as a global standard in 2010 (see www.iso.org).

The distinct moves towards convergence and divergence underline the complex nature of standards development, and reflect concerns with the scope of specific standards, the manner by which compliance is verifiably monitored, the motivations of distinct actors driving the standards agenda, as well as the interests of those parties that seek to implement the standards. In the highly contested arena of environmental and social norms, where in addition to the interests of national and international regulators, national and international business, various NGOs (including single issue organizations) have been highly influential, attempts to bring about convergence remain difficult to negotiate. This is despite the ISO 26000 and UN Global Compact initiatives. Consequently, in these areas we continue to observe a contestation of distinct standards, labels and company codes of conduct seeking to address similar themes, but doing so with different levels of emphases and with different forms of monitoring and verification.

\subsection{Global governance}

Within the area of global governance, the typology indicated two especially important consequences emerging with the rise of global standards. First, there is the relative decline of national actors, especially public actors. This includes the weakening of national regulatory bodies, as well as the deterioration in many countries of public monitoring agencies such as labour inspectorates. ${ }^{9}$ Second, there is the growing

8 For a detailed overview of the Global Compact and the emerging relationship between international business and the United Nations, see Utting and Zammit (2006).

9 For a fascinating discussion on the ways in which labour inspectorates can succeed, and have succeeded in, promoting labour compliance in parts of Latin America, see Piore and Schrank (2006) and Schrank (2006). 
significance of regional and international actors - both public and private - in the process of standards formulation and monitoring. Two particular drivers are especially important. On the one hand, global brands and TNCs who seek to balance the risk to their brand identity from publicity campaigns targeted against them on social, labour and environmental concerns and the governance costs of implementing compliance to such standards throughout their extensive, complex and globally dispersed value chains. On the other hand, global NGOs (and to lesser extent labour organizations) who seek to promote particular concerns on environment, labour and social issues. The emergent trend in global governance on environmental and social standards is the need to bring the interests of these two, potentially opposing, parties closer together. These developments are apparent at various levels.

At the regional level, one of the clearest examples of national regulatory functions on specific areas of standards (such as health and safety, especially food safety) giving way to regional initiatives is seen in Europe with the EU taking on the central role in formulating a range of standards addressing health, safety and environmental considerations that apply to all member states. Gibbon with Memedovic (2006) provide a useful discussion on this in the context of organic standards, while Codron et al. (2005) outline how European supermarkets have responded to European food safety and minimum quality standards in the meat industry.

In the setting of most technical product standards as well as certain process standards, the ISO's significance as the international body coordinating the work of national standards agencies is paramount. ${ }^{10} \mathrm{~A}$ key challenge for national agencies is to ensure that they become members of the relevant technical committees (TCs) of the ISO engaged in the formulation of standards that are of particular significance to their countries. For many developing countries, with weak standards infrastructure and poorly resourced national standards agencies, this is not possible, thereby effectively excluding them from discussions associated with formulating standards that may be critical to them. Hence, the dominance of OECD standard bodies in the workings of the ISO. ${ }^{11}$ However, some of the larger developing nations have managed to get on to some of the ISO's TCs - usually as an 'observer' member, but in the case of some countries as a more powerful and active 'participant' member engaged in the on-going activities and deliberation of the respective TCs.

A few developing countries with better resourced standards agencies, have also managed to play more a active role in the ISO's standards decision making process by taking on the key role of providing the 'secretariat' of particular TCs. China's SAC (Standardization Administration of China), for example, maintains the secretariat for eight TCs committees of the ISO, in addition to being a participating or observer member of over 600 other TCs. Malaysia, the world's leading rubber and palm oil exporter has ensured that its national standards agency (Department Standards Malaysia) is the secretariat for the TC on rubber and rubber products (TC45) and

10 There are of course separate international agencies that deal with specific standards that fall within their purview. These include, for example, the International Civil Aviation Organization (ICAO) for air navigation and safety standards; the UN's International Telecommunications Union (ITU) on telecommunications standards; and the International Electrotechnical Commission (IEC), which sets standards on electrical and electronics related technologies.

11 The national standards bodies of France, Germany and the UK have the highest level of participation in the various technical committees (TCs) of the ISO, being members of 730,728 and 720 TCs, respectively (see www.ISO.org). 
a participating member of the TCs on oil and food oils (TC34/SC11). Similarly, India one of the world's leading exporters of tanned leather and leather products has its BIS (Bureau of Indian Standards) holding the secretariat of the TC for leather and leather products, and is a participating member of the TC on information technology (JTC1), the TC on steel and steel products (TC17) and the TC on textiles (TC38) amongst others. Brazil, along with Canada, is one of two secretariats for the powerful TC (TC207) dealing with environmental management systems. Such examples suggest that some developing countries can take a more strategic role in the key global arenas where technical and process standards are set, especially in sectors in which they have a significant global presence. But they remain the exception. Most developing nations continue to be 'standard takers' rather than 'standard setters'.

The second observation about global governance around standard setting is the increasing importance of private actors. In some sectors (such as wood-based products), and in particular areas of attention (such as environmental standards), international NGOs have become important actors engaged in defining standards that become accepted industry-wide, as well as in monitoring and compliance activities. Hence, environmental NGOs such as the Worldwide Fund for Nature (WWF) and the Soil Association in the UK have, for example, been at the forefront in formulating - often in conjunction with international business - standards effecting environmental stewardship (such as the Forestry Stewardship and Marine Stewardship Councils), and organic food production (Clapp, 1998, 2005). In the area of labour and social standards, a number of NGOs have emerged as key players in specific sectors. Thus, the FLA (Fair Labour Association), WRC (Workers Rights Consortium) and WRAP have been important actors engaging as standards monitoring and compliance bodies in labour intensive sectors such as garments, footwear and sports goods (O'Rourke, 2003). The UK's Fairtrade Foundation, the owner and UK licensee of the 'Fairtrade' logo has at its core 14 different charities, or NGOs, most of which are directly engaged on development oriented agendas (www.fairtrade.org.uk).

Private sector companies have also come together in particular areas to develop coordinated standards setting bodies and codes. The Electronic Industry Code of Conduct (www.eicc.info), for example, is an attempt by the leading brand manufacturers, component producers and contract manufacturers in the computer related electronics sector to agree on a common code addressing health safety, labour and environmental concerns. Another example is in the area of farm assurance, or good agricultural practices (GAP) standards where European supermarkets came together in 1997 to form EUREP-GAP as a coordinated standard setting framework that would apply to all their farm-based suppliers. In September 2007 EUREP-GAP became GLOBAL-GAP, reflecting the ways in which the harmonization efforts pioneered by European supermarkets had spread to similar initiatives across the world.

As the discussion earlier has shown, there are what appear to be somewhat contradictory tendencies emerging on standards. In some areas, there is greater convergence, but then that convergence can decline where technological considerations imply the need for more specialized standards. In other areas, such as environmental, labour and social standards, convergence initiatives that bring together the interests of diverse public, but especially private actors, have helped the development of common standards and codes. Yet individual company codes of conduct, and in some cases specialized sector specific codes and standards also proliferate and grow. These developments underline the fact that nature of political and institutional governance 
is changing. Global governance is increasingly undermining the regulatory powers of national governance. At the same time, convergence measures increasingly require more complex networks of various global actors, especially of NGOs and international business actors. In the next section, I turn to the issue of how standards influence the governance of inter-firm ties within the value chain.

\section{Global standards and GVC governance}

The discussion earlier has concentrated on the ways in which global standards point to new forms of global governance, and the key roles played by distinct types of international public and private actors in this process. I now turn to the ways in which adoption of standards influence the nature of governance within inter-firm ties in GVCs. In what ways does compliance with standards change how value chains are organized? Do standards lead to a higher level of explicit coordination of ties between global retailers and lead firms and their developing country suppliers? Or alternatively, does compliance result in more market-based transactions?

Understanding the power of global lead firms to organize and structure value chains has been one of the core elements of the GVC approach (Gereffi, 1999; Humphrey and Schmitz, 2004; Gereffi et al., 2005; Gibbon and Ponte, 2005; Altenburg, 2006). This is based on a recognition of the asymmetrical power exercised by lead firms, and the consequences that this implied for local producers who sought to enter into GVCs. In terms of understanding such forms of power, the nature of governance of inter-firm ties within the chain has largely been analysed through the lens of transaction costs. Reducing the costs of organizing the chain, coordinating dispersed and varied suppliers and dealing with concerns such as asset specificity lie at the heart of what lead firms do. This can either take place through market transactions at one extreme or through internalized hierarchical forms of organization at the other extreme. In between these extremes lie a number of distinct forms of network relationships. Thus, Gereffi et al. (2005) outline five forms of governance of value chain ties: market based, modular networks, relational networks, captive networks and hierarchical structures. They go on to state that the particular form of governance that prevails in a given value chain at a given point in time is determined by the complexity of transaction, the codifiability of information and the capability of suppliers.

Coe and Hess (2007) have critiqued this framework as being highly stylized and representing only ideal forms. They stress that different forms of governance may be apparent in a given chain (or global production network) at any point. This point is also noted by Ponte and Gibbon (2005) who distinguish between 'forms of co-ordination' and 'modes of governance' and argue that 'a GVC may be characterized by different forms of co-ordination in various segments, yet a single and relatively coherent mode of overall governance' (Ponte and Gibbon, 2005, p. 3). Coe and Hess (2007) go on to state that the focus on a transaction costs-based understanding of ties between suppliers and lead firms only addresses 'inter-firm' governance. It fails to account for either 'intra-firm' governance or for 'institutional and political' governance that necessarily informs and impacts on intra and inter-firm governance.

How do standards influence the nature of governance- both the governance of interfirm ties as well as institutional governance? Standards are critical to 'inter-firm' ties because they provide the potential to codify complex forms of information that can 
reduce transaction costs (Nadvi and Wältring, 2004; Gereffi et al., 2005; Gibbon and Ponte, 2005). Thus, through the implementation of standards, especially technical product, but also process standards, the codifiability of information can be improved and governance of inter-firm ties can move away from relatively more hierarchical forms to more modular or market-based interactions which require less coordination by lead firms. As Gereffi et al. (2005), Sturgeon (2003) and Hess and Coe (2006) have observed technical product standards have been essential to the workings of technically complex sectors, such as electronics and telecommunications, facilitating more modular relationships between highly competent suppliers and lead firms.

On process standards, it is less clearly apparent that codification through standards implies a necessary move in the governance pendulum from greater to less coordination by lead firms. It depends very much on the standard, the form of compliance monitoring and the risks for lead firms associated with compliance failure.

If standards ensure codifiability that reduces transaction costs associated with the governance of the chain, then the most important standard in this regard has to be the ISO 9000 quality management standard. In part, this explains why the standard has proved to be so popular, especially for supply chain management. In some cases, it is argued that the presence of ISO 9000 certification has, in effect, loosened ties between global lead firms and local suppliers with an increasing tendency towards arms-length relationships between certified suppliers and lead firms further up the value chain (Nadvi, 1999, 2004). Yet, there are also challenges about the effectiveness of the ISO 9000 standard in promoting greater efficiency in supply chain management, in delivering effectively on quality management and in ensuring proper verification (Seddon, 2000).

On environmental, food safety and labour and social standards the evidence is less clear. Take, for example, the global horticulture value chains where compliance pressures on food safety standards as well as environmental and labour concerns have grown over the past two decades, along side significant attempts to harmonize standards. Food safety standards are covered by HACCP (Hazard Analysis Critical Control Points) as well as the EU's food safety regulation. In addition, there are two key private sector initiatives that have sought to bring about harmonization on agrofood related standards. First, EUREP-GAP (now re-termed as GLOBAL-GAP) that seeks to promote harmonization through a voluntary code that is agreed to by leading supermarket retailers and suppliers. EUREP-GAP provides a common code on good agricultural management practices, environmental concerns such as around pesticide residues, as well as labour and social parameters. Second, there is the British Retail Consortium's (BRC) Global Standard on food, food packaging and distribution. Initiated in 1998, the BRC has become a widely accepted core standard on food safety and hazard analysis - which includes HACCP - and an important aspect of due diligence required by UK supermarkets from their agro-food supply chains. Finally, there is a further public-private programme - the UK's ETI - to which all the leading UK supermarkets have joined and have agreed to adopt the principles on social and labour practices underlying the ETI base code within their supply chains.

Yet, despite these developments in standards codification, the nature of governance in the structure and organization of the global horticulture value chain linking leading supermarkets to agricultural suppliers across the world appears to have not moved universally towards either modular or market-based ties. In some areas there are signs that standards certification, as one element of industrial competence of suppliers, have 
helped to promote cut throat market-based transactions as supermarkets use reverse internet auctions to choose the cheapest of standards compliant suppliers, and push inventories, costs and risks further down the chain (see Ponte, 2007 in the case of the wine industry).

The power of supermarkets in organizing value chains in such a manner within the food, and now also garments and consumer durables sectors, is also highlighted in the work of Reardon et al. (2007). Hughes (2005) has also underlined how UK retailers in the food and clothing sector have adopted quite distinct approaches in terms of the organizational framework for implementing ethical monitoring and sourcing. These range from arms-length transaction, greater coordination and adopting a developmental approach. However, as Dolan and Humphrey (2000, 2004) observed, supermarkets (and importers), also engage in explicit coordination with independent audits and spot checks of suppliers to assess non-compliance especially for new suppliers and in product lines where compliance concerns can be especially paramount.

Ponte and Gibbon (2005) have used the framework of convention theory to argue that standards in the agro-food sectors reflect both 'civic' and 'industrial' conventions. Yet, drawing from their extensive studies on the implementation of agro-food standards in various sectors in sub-Saharan Africa, it is apparent that the specific form of governance of the value chain is determined not only by the implementation of particular standards, but also by other commercial considerations. Hence, as Ponte (2007) shows for South Africa's wine industry, the nature of governance is such that lead firms (e.g. UK's big five supermarkets) effectively operate captive or a modular forms of governance dependent on the particular quality segment of the market that South African vineyards are supplying. Standard certification-to HACCP, ISO 9000 and BRC global standards are necessary to enter the chain, but they do not determine the nature of inter-firm ties. Standards compliance provides one element of codifiability and supplier competence, yet the nature of governance is often determined by other commercial factors.

The evidence on the relationship between standards and value chain governance is equally mixed when one turns to the area of labour and social standards. As mentioned earlier, labour and social standards have been addressed through company codes of conduct, but are also being increasingly harmonized through a number of initiatives that bring together leading corporate actors and global NGOs, trade unions and international bodies such as the ILO. Such initiatives include the UK's ETI base code, Social Accountability International's SA8000, the ISO 26000 social responsibility standard which is currently being developed and the UN's Global Compact.

The presence of these harmonized standards, all of which conform to the core ILO labour conventions, and in some cases also address human rights and environmental concerns, would suggest that there is the potential for greater codifiability of information on issues surrounding labour and work practices within the value chain. Such codified knowledge could lead to a lowering of transaction costs associated with governing the chain by lead firms. This could imply a move from relatively hierarchical or captive network arrangements to modular, relational and possibly market-based governance. It is unclear, however, that this is as yet the case. One key element is the risk to brand integrity that lead firms potentially face from non-compliance on labour issues by their dispersed global suppliers. Where such risks are high, or where the potential costs to brand integrity are sufficiently large, lead firms while seeking to promote harmonization of labour and social codes, would also want to ensure auditing, 
inspection and control of their supply chain to minimize such risks. The next section provides a more detailed discussion of this in the context of the Sialkot case study and the manner in which child labour concerns have impacted on the nature of governance in value chain ties that local producers have with the leading global sports good brand merchandisers.

\section{Child labour and governance in the Sialkot sporting goods cluster}

The sports good cluster in Sialkot, Pakistan is renowned for the export of soccer balls. Its hand-stitched balls are considered the best in quality and are consistently used in leading international competitions, from football World Cup and Olympic tournaments and by major clubs across the world, including the UK's premiership. Manufacturing is undertaken by over one hundred exporting firms who also use subcontractors for some of the more labour intensive processes of hand stitching. ${ }^{12}$ Much of the hand stitching is carried out by women. The cluster supplies most of the leading branded merchandisers in global sports goods industry-including Nike, Adidas/Reebok, Umbro, Pentland (Mitre), Puma, Decathlon, Select and Mikasa. The total exports of soccer balls from the cluster came to US\$146 million in 2005-2006 (Sialkot Dry Port Trust).

In 1996, international media reports highlighted the presence of child workers in the Sialkot cluster. ${ }^{13}$ These revelations led to demands from Western consumer groups, trade unions and NGOs for a boycott of Sialkot-manufactured footballs. For many of Sialkot's brand buyers, the challenge to brand reputation from the presence of child workers within their Sialkot supply chain was substantial. In order to remain within the supply chains, buyers demanded that local suppliers meet ILO labour conventions on child labour and comply with their codes of conduct.

In February 1997, the Sialkot Chamber of Commerce and Industry (SCCI), Government of Pakistan, ILO, UNICEF, the World Federation of Sports Goods Industries (WFSGI) and FIFA (the international federation of football associations) signed the 'Atlanta Agreement' with the aim to remove child labour from the cluster. This was a multi-stakeholder, public-private partnership initiative that was actively supported, and financed, by leading international donors, in particular the United States. ${ }^{14}$ The Atlanta Agreement had a two-pronged agenda to combat child labour in the cluster. The first was a child labour prevention and monitoring programme, established and run in the cluster by the ILO's International Programme for the Elimination of Child Labour (IPEC). The second was a social protection programme, run by UNICEF and Save the Children Fund (SCF-UK) as well as the Pakistan government and Pakistani NGOs. ${ }^{15}$ This sought to address the root causes of child labour through interventions on poverty alleviation and education and to promote the

12 Some studies cite as many as 400 producers located in the cluster (Khan 2007), but this appears to include numerous small subcontractors.

13 For a discussion on the way in which the international media campaign on child labour in Sialkot unfolded, see Khan (2007).

14 See Nielsen (2005) for a similar initiative in the Bangladesh garment industry.

15 Khan (2007) critiques the Atlanta Agreement programme as representing a 'development discourse' which imposes Western notions of childhood and education that fail to take account of the perspectives and agency of local child workers in Sialkot. 
social welfare of child stitchers and their households. The social protection programme included support for education, schools, training and income generating activities.

In addition to donor support, the industry-both at the global and the cluster level was expected to play an active part in the programme. There were financial contributions from FIFA and continuing support from WFSGI-which represented the leading brand buyers, as well as financial contributions to the monitoring programme, channelled through the SCCI, from local Sialkot producers who joined the initiative. In addition, the local chamber established a corporate social responsibility (CSR) cell and a Child and Social Development Organization (CSDO) with the aim to promote social development programmes within the cluster, and to coordinate philanthropic and social protection initiatives from the industry.

As a result of this complex multi-stakeholder partnership, which brought together a network of global and local actors, representing industry, labour federations, NGOs, government and international agencies, it appeared that not only had the cluster found a way to address the child labour issue, but it had also engaged with a broader developmental agenda in which business interests were socially embedded into local developmental and societal concerns. Thus, by 2000, 68 out of a total of 90 exporting firms in the cluster, accounting for over $75 \%$ of the cluster's total production, were being voluntarily monitored through the IPEC programme and overall export levels had risen (Nadvi, 2004). In addition, there were improvements in education through school development programmes and school management committees supported by SCF, through the universal primary enrolment programme managed by UNICEF, through vocational training initiatives and through a number of income generation and micro-credit programmes run through the government and national NGOs (Husselbee, 2000).

As planned in 2003, the programme moved into a second, locally sustainable, phase whereby ILO-IPEC's monitoring activities was taken over by a newly formed local nonprofit agency - the Independent Monitoring Association for Child Labour (IMAC). IMAC used IPEC's monitoring approach, procedures and technologies and engaged most of IPEC's local staff. IMAC's governing body included representatives of trade unions, government, local academia, the WFSGI and most importantly the local manufacturers. Unlike the donor funded IPEC, IMAC was largely supported through funding from the local industry, and through charges for its monitoring services.

Most global buyers insisted that their local suppliers join the ILO-IPEC, and subsequently the IMAC, programme for monitoring purposes. With few exceptions, independent monitoring by ILO-IPEC, and subsequently IMAC, was seen to be a credible basis for continuing sourcing from the cluster. However, some leading brandname buyers (such as Nike and Adidas/Reebok) also undertook direct monitoring of their suppliers. In the case of Nike, its decision to adopt its own monitoring (through internal and third party monitors) was based on first its concern to retain all production in pre-designated manufacturing stitching centres, and second to monitor not just on child labour but also other labour and environmental, health and safety compliance issues - such as social security payments, time keeping and chemical storage (Nike, interview, 12 January 2008). The IPEC/IMAC monitoring agenda was thus seen as being both insufficiently comprehensive in that it did not go beyond child labour and potentially risky.

Nevertheless, Sialkot's multi-stakeholder child labour monitoring initiative had significant implications for governance. At the level of institutional and political 
governance', the Atlanta Agreement brought together a range of policy actors - at the local and global as well as the public and private level concerned with the cluster and with promoting local economic and social development as well as maintaining the integrity of the soccer ball supply chain. The monitoring scheme developed through the IPEC programme was considered so comprehensive that elements of it were copied in a similar soccer ball manufacturing cluster across the border in Jalandhar, India.

There were also consequences for inter-firm governance. This was seen at two, interconnected, levels. First, was in the nature of governance ties within the cluster through changes in the pattern of local subcontracting. Second, were changes in governance ties with lead firms, namely the brand buyers, in the GVC. Let me take first the issue of cluster-based inter-firm governance. The cluster historically relied heavily on rural home-based workers to carry out the more labour-intensive tasks in producing soccer balls. This was where child labour was most common. Subcontractors acted as intermediaries between exporting firms and household stitching units. With the need for effective and cost-efficient monitoring, home-based work began to give way to production in designated stitching centres set up and run by individual producers. Stitching centres thus became mini-factories undertaking work directly, and solely, for one export manufacturer. As a result, subcontractors and workers became more closely tied with manufacturers.

Ties with buyers also changed. Given their vulnerability to child labour scandals within the media and the risks that this posed to brand integrity, global buyers were forceful in implementing changes in practices on the part of their suppliers, the cluster's larger producers. In many cases this involved an internalization of activities formerly subcontracted to home-based workers. In response to pressure from buyers, some large firms set up centrally located factories to which workers were transported from distant villages. This allowed better monitoring of quality standards and labour norms. As suppliers to the leading brand names, such firms also had to adhere to the buyer's code of conduct. Moreover, some of the leading brand buyers invested in relationships with local NGOs. Such NGOs were engaged to monitor supplier's labour practices. It also allowed some brands to undertake local philanthropy, channelling resources through local NGOs to promote education and schooling for former child workers. In some cases, brand buyers encouraged their main suppliers to adopt the principles and values of CSR. This included on-site medical facilities to workers, access to cheap credit and to fair-price shops (Nadvi, 2004).

Nike's 2006 'pull-out' seriously challenged the earlier, and very positive, conclusion on Sialkot's response to child labour (Nadvi, 2004). Nike was at the time the cluster's biggest buyer of soccer balls with a strong brand-based CSR programme. It sourced from the largest sports good producer in the cluster, an enterprise with its own CSR agenda and known locally for good working conditions and worker benefits. If the top supplier and the top buyer could get it wrong, did Nike's action then point to a more systemic and fundamental problem within the cluster and with the monitoring system? ${ }^{16}$ Although Nike has, since resumed sourcing from the cluster, albeit from a different supplier, the 'pull-out' raises questions ways in which labour standards have been

16 Nike note that while their decision to withdraw sourcing from their then supplier was associated with continuing concerns on child labour and other labour related code violation, there were also questions related to the supplier's competency to address supply chain management concerns relating to on-time product delivery and quality (Nike interview 12 January 2008). 
adopted within the cluster. Moreover, while Nike did not use IMAC to monitor its supplier, and had stopped participating in the IPEC programme in Sialkot since 2000, the significance of its actions were such that they raised questions for both the institutional and political governance under which the multi-stakeholder programme had developed in Sialkot, as well as for inter-firm governance.

As in 1997, there has been a multi-stakeholder political and institutional response with the Pakistan Government, the ILO, the WFSGI, trade unions, NGOs and buyers being involved. This emerged in the form of the February 2007 'Sialkot Initiative' which would lead to a wider 'Sialkot Compact' that would eventually seek to promote 'decent working conditions' and compliance with core labour standards in the cluster (ILO, 2007). In effect, this responds to the concerns of some leading brands to go beyond child labour in terms of labour standards compliance within the cluster.

It is too early to state how this initiative will take shape. Nevertheless, what is apparent is that the transparency of the monitoring process that had initially been so successful was now seen as flawed in terms of its accountability and governance mechanisms. Hence, while IMAC continues to operate, and under the new initiative will obtain further support to strengthen its functions, a number of leading brand buyers have also turned to greater self and independent third party assessment of their suppliers. More worryingly for the cluster, export sales levels appear to be declining as buyers begin to consider alternative sourcing locations in Thailand, Vietnam and China where pressures arising from child labour may not be so acute. In addition, changes in the technology of machine stitching have led to improvements in the quality of machine-stitched balls. This can seriously undermine Sialkot's niche as the leading supplier of premium match quality footballs as demand for higher quality machine stitched balls rise. Machine stitched balls are largely sourced from China and Thailand where concerns on child labour are not present.

The Nike 'pull-out' suggests that what was an effective form of global governance in 1997, in terms of the network of actors that came together to shape and implement the Atlanta Agreement, had been undermined by 2006. The 2007 Sialkot Initiative document suggests that one area where there was a potential governance failure was in the dominance of local producers within the governing body of IMAC. A key element of the effectiveness of the 1997 Atlanta Agreement was the active participation of international actors in the process-including global buyers (represented through WFSGI and FIFA), the ILO, UNICEF as well as leading international donors. By 2006, many of these international players were less active in the cluster, or in the workings of IMAC. The Atlanta Agreement was largely financed through support provided to ILO-IPEC by the United States. In 2003, when ILO-IPEC effectively withdrew, IMAC's funding, resources and monitoring manpower declined. Yet, if there was a failure of external actors to continue to be engaged in the governance framework on labour standards within the cluster, there was also a clear failure on the part of the local cluster - especially its producers - to take ownership of the child labour standards agenda.

Finally, while the immediate outfall of the 'pull-out' may have been addressed, there are implications for inter-firm governance as well. Observations from key respondents indicate that global buyers now take a more active role in supply chain coordination on compliance issues. Hence, buyers augment IMAC's monitoring activities with their own independent audits of their suppliers. Moreover, there is a perception voiced by some buyers that if the cluster, despite a decade long programme of intervention on 
child labour, has failed to adequately take ownership of the child labour agenda and effectively deal with it, then the GVC could move on to alternative suppliers.

\section{Conclusion and questions for further research}

This article sought to assess the relationship between global standards and GVCs through the lens of governance. Using the terminology put forward by Coe and Hess (2007) it concentrated on analysing the ways in which standards have affected institutional and political governance. It pointed to attempts at convergence on standards, especially on social, labour and environmental aspects of process standards, which involved complex networks of diverse public and private, local and global actors. This suggests new forms of global governance, which increasingly challenge the ability of nation states in shaping the 'rules of the game'. Some countries have managed to assert their interests within organizations such as the ISO, and in the area of technical product standards. In process standards, however, developing countries remain very much on the back foot, passive standard takers who are constantly being challenged to address new concerns on compliance.

The second dimension of governance that this article raised is that of inter-firm governance within the value chain. The governance framework put forward by Gereffi et al. (2005) argues that standards can help promote the codification of knowledge in ways that lower transaction costs within value chains. One consequence of this is that the need for greater coordination of the chain will diminish. As has been outlined, the evidence on this is mixed. In some areas, such as product and technical standards as well as quality management standards, this appears to be the case. It is less clear, however, that the need for chain coordination has declined with the imposition of process standards around environmental, labour and social concerns. A great deal hinges here on the vulnerability and exposure to risks for lead firms within the chains, especially brand recognized corporations, to non-compliance within their supply chains. The risks of exposure are as great as they were before the agenda of standards took hold. Hence, despite attempts at convergence on standards in arenas such as environmental and social concerns, company codes of conduct not only continue to remain but also are increasingly being broadened to cover a wider set of issues. In some cases, retailers are emphasizing their specific codes of conduct as a marketing tool to underline their socially responsible, even ethical, sourcing practices. In part, this underlines Ponte and Gibbon's (2005) observation that there could be within a given GVC different forms of coordination apparent at different points of the chain.

The evidence from Sialkot highlights the fact that even the most well developed multistakeholder initiatives aimed at addressing standards compliance, in this case child labour standards compliance, are prone to being undermined by the stray cases of noncompliance. Thus, effective monitoring can very quickly become ineffective. Clearly there is a need for further research into this. Do the recent challenges to multistakeholder initiative suggest failures within the ways in which the monitoring of child labour is undertaken in the Sialkot sports goods cluster? Did the exit of international actors - especially the ILO - in 2003 when the donor funded initiative moved to a 'locally sustainable' model undermine the effectiveness of the programme? Or, is the challenge related to the fact that programme restricted itself solely to child labour and did not encompass other labour, environmental and social compliance concerns 
that some leading international buyers (and some international NGOs) were keen to address. These are some of the questions on which further detailed empirical analysis from the Sialkot cluster could elicit useful policy conclusions.

The Sialkot experience also raises another issue. Between the initial challenge on child labour in 1996 and the 2006 Nike 'pull-out', a decade has passed. A decade in which there has been a concerted effort through the Atlanta Agreement to monitor and prevent children from working in such export industries, as well as develop a wide range of social protection and social provisioning measures aimed at tackling the roots of child labour. And yet, despite this effort - which ostensibly brings together a wide range of local actors in business, labour federations, NGOs and the state, the cluster remains prone to child labour. Why then do the values implicit within the ILO labour conventions on worst forms of child labour not take hold in the cluster?

To address the question of why global values on labour norms are not 'accepted' within local supplier/cluster contexts, one has to raise a further question. Namely, what are the outcomes of labour and social standards for local workers and producers from implementing particular labour standards? If outcomes can be shown to be positive - in terms of improved incomes, employment, better working conditions and reduced vulnerabilities then it may become easier to accept the values and virtues implicit in specific labour standards. If outcomes are at best ambiguous and at worse negative, then it is more than likely that the standard is seen as a necessary but external 'evil' that has to be responded to, but that does not necessarily change local social perceptions on the values implicit in the standard. It is a moot point, therefore, whether despite a decade of policy activity around child labour, social attitudes on child labour within the clusters - amongst businesses, amongst workers and within the wider local community have changed sufficiently to view it as an evil that should be eradicated.

Khan (2007) argues that there is a disjuncture between the 'development discourse' promoted by international donors concerned with eradicating child labour, and a local discourse amongst stitchers that values home-based working and the transmission of skills from one generation to the next. However, the Atlanta Agreement did in fact seek to address some of these concerns by distinguishing between child labour and child work (the latter allowing for some work as part of a child's vocational training), by allowing for small village based stitching centres and by stressing the importance of education improvement, primary school enrolment, skill development and income generation programmes alongside child labour monitoring as a concerted agenda to address child labour. The continued questions about the child labour programme in Sialkot imply the need for greater attention in assessing the social provisioning elements of the multi stakeholder initiative, and the outcomes of this for child workers and the wider community in Sialkot.

This leads to the broader subject of outcomes. To date detailed evidence on outcomes for workers from the implementation of labour standards and corporate codes has been limited. ${ }^{17}$ Barrientos and Smith (2007) report that implementation of the ETI's base code has not led to substantial gains for workers beyond the area of occupational health concerns. Suppliers continue to have to balance the competing challenges posed by their

17 There has been some work in the context of gender corporate codes and GVCs, see, for example, Barrientos et al. (2003); and Tallontire et al. (2005). 
buyers to meet shorter delivery times and take on greater risks, while at the same time not exceed overtime stipulations underlined in their buyer's codes of conduct. Thus, despite compliance to codes, harassment and coercion of workers around issues of overtime continues to be one of the most commonly cited complaints by labour. Hughes (2005) points to the differing practices adopted by UK retailers - from those who see compliance to ethical norms as a separate aspect to their buying strategies, and where commercial pressures to reduce costs and squeeze suppliers on sourcing practices remains the norm, to those few retailers who adopt a more enlightened developmental approach to sourcing ties.

Locke and Romis (2007) from their work on Nike's garment suppliers in Mexico provide a very insightful observation. Namely, that returns for workers tend to improve in those factories where compliance with codes of conduct are also linked with changes in work organization. Thus, they show that in contrast to garment factories that work on a Fordist form of production organization, suppliers that had adopted the principles of flexible specialization through multi-skilled workers operating in groups, working with incentive bonuses and empowered to stop the production line to ensure quality had better outcomes for workers - in terms of wages and working conditions, for firms - in terms of productivity gains and efficiency and in terms of compliance.

This is a key point in that it underlines that further research on the subject of outcomes from the implementation of standards for local producers, workers and the communities in which they are located must also address the issue of intra-firm governance. In the context of labour standards, understanding how decent working conditions do not imply solely higher costs, but can have positive efficiency gains for firms and workers through productivity enhancements is critical. Such productivity enhancements are potentially more likely to deliver on sustainable outcomes for workers. Moreover, bringing about such productivity enhancements requires a refocusing of attention on the labour and work process within the firm, namely addressing intra-firm governance and the relationship between labour and capital. In failing to do so, as the evidence from Sialkot would suggest, gains from implementation of standards remain weak and fragile. And thus, the failure to take ownership of the agenda on standards, and to socially embed the values implicit in external standards into the local milieu, implies that global standards will have weak governance outcomes for GVCs. This implies a need for further research to engage with the local social context - which includes norms and values as well as gender and household relations and the ways in which these impact on local work practices and work organization. Compliance with global standards may prove ineffective if such standards are not socially embedded.

\section{Acknowledgements}

The author benefited from discussions at the 'Global Production Networks: Debates and Challenges' workshop held at the University of Manchester, UK in January 2007, and the 'Just Supply Chains' conference at the Massachusetts Institute of Technology (MIT), Cambridge, USA in January 2008. He thanks Peter Lund-Thomsen and anonymous referees for detailed comments, and remains solely responsible for all errors. 


\section{References}

Altenburg, T. (2006) Governance patterns in value chains and their developmental impact. European Journal of Development Research, 18(4): 498-521.

Bair, J. (2005) Global capitalism and commodity chains: looking back, going forward. Competition and Change, 9(2): 153-180.

Barrientos, S., Dolan, C., Tallontire, A. (2003) A gendered value chain approach to codes of conduct in African Horticulture. World Development, 31(9): 1511-1526.

Barrientos, S. and Smith, S. (2007) Do workers benefit from ethical trade? Assessing codes of labour practice in global production networks. Third World Quarterly, 28(4): 713-729.

Clapp, J. (1998) The privatisation of global environmental governance: ISO 14000 and the developing world. Global Governance, 4(3): 295-316.

Clapp, J. (2005) Global environmental governance for corporate responsibility and accountability. Global Environmental Politics, 5(3): 23-34.

Codron, J.-M., Girard-Hèraud, E., Soler, L.-G. (2005) Minimum quality standards, premium private labels and European meat and fresh produce retailing. Food Policy, 30(3): 270-283.

Coe, N. M., Dicken, P., Hess, M. (2008) Global production networks: realizing the potential. Journal of Economic Geography, 8(3): 271-295.

Coe, N. M. and Hess, M. (2007) Global production networks: Challenges and debates. Paper prepared for the GPERG workshop, University of Manchester, 25-6 January 2007. Available online at: http://www.sed.manchester.ac.uk/geography/research/gpe/downloads/Manchester_ Jan07_positionpaper_final.pdf. [Accessed 12 October 2007].

David, P. (1995) Standardisation policies for network technologies: the flux between freedom and order revisited. In R. Hawkins, R. Mansell, J. Skea (eds) Standards, Innovation and Competitiveness: The Politics and Economics of Standards in Natural and Technical Environments. Aldershot: Edward Elgar.

Dicken, P. (2003) Global Shift: Reshaping the Global Economic Map in the 21st Century, 4th edn. London: Sage.

Dolan, C. and Humphrey, J. (2000) Governance and trade in fresh vegetables: the impact of UK supermarkets on the African horticulture industry. Journal of Development Studies, 37(2): $147-176$.

Dolan, C. and Humphrey, J. (2004) Changing governance patterns in the trade in fresh vegetables between Africa and the United Kingdom. Environment and Planning A, 36(3): 491-509.

Finger, M. and Tamiotti, L. (1999) New global regulatory mechanisms and the environment: the emerging linkage between the WTO and the ISO. IDS Bulletin, 30(3): 8-15.

Gereffi, G. (1999) International trade and industrial upgrading in the apparel commodity chain. Journal of International Economics, 48(1): 37-70.

Gereffi, G. (2005) The global economy: organization, governance and development. In N. Smelser and R. Swedberg (eds) Handbook of Economic Sociology, Princeton: Princeton University Press. 160-182.

Gereffi, G., Humphrey, J., Sturgeon, T. (2005) The governance of global value chains. Review of International Political Economy, 12(1): 78-104.

Gereffi, G. and Mayer, F. (2006) Globalisation and the demand for governance. In G. Gereffi (ed.) The New Offshoring of Jobs and Global Development. ILO Social Policy Lectures, Geneva: International Institute of Labour Studies.

Gibbon, P. and Memedovic, O. (2006) Decoding organic standard-setting and regulation in Europe (1991-2005). UNIDO Working Papers, Vienna, UNIDO.

Gibbon, P. and Ponte, S. (2005) Trading Down: Africa, Value Chains and the Global Economy. Philadelphia: Temple University Press.

Hawkins R., Mansell R., Skea J. (1995) (eds) Standards, Innovation and Competitiveness: The Politics and Economics of Standards in Natural and Technical Environments. Aldershot: Edward Elgar.

Held D. and McGrew A. (2002) (eds) Governing Globalization: Power, Authority and Global Governance. Cambridge: Polity Press. 
Henderson, J., Dicken, P., Hess, M., Coe, N., Yeung, H. W.-C. (2002) Global production networks and the analysis of economic development. Review of International Political Economy, 9(3): 436-464.

Hess, M. and Coe, N. M. (2006) Making connections: global production networks, standards, and embeddedness in the mobile-telecommunications industry. Environment and Planning A, 38(7): 1205-1228.

Hess, M. and Yeung, H. W. (2006) Guest editorial: whither global production networks in economic geography? Past, present and future. Environment and Planning A, 38(7): $1193-1204$.

Hughes, A. (2005) Corporate strategy and the management of ethical trade: the case of the UK food and clothing retailers. Environment and Planning A, 37: 1145-1163.

Hughes, A. (2006) Learning to trade ethically: knowledgeable capitalism, retailers and contested commodity chains. Geoforum, 37(6): 1007-1019.

Humphrey, J. and Schmitz, H. (2004) Governance in global value chains. In H. Schmitz (ed.) Local Enterprises in the Global Economy. Cheltenham: Edward Elgar.

Husselbee, D. (2000) NGOs as development partners to the corporates: child labour stitchers in Pakistan. Development in Practice, 10(3-4): 377-389.

ILO (2007) The Sialkot initiative 2007. Government of Pakistan - ILO Tripartite Workshop, Islamabad, Pakistan, 21-22 February 2007. Available online at: http://www.wfsgi.org/pages/ committees/csr/sialkot/Sialkot_Initiative.pdf [Accessed 25 October 2007].

ISO (2007) The ISO Survey of Certifications 2006. Geneva: International Standards Organisation. Available online at: http://www.iso.org/iso/survey2006.pdf [Accessed 5 January 2008].

Kennedy, L. (1999) Cooperating for survival: tannery pollution and joint action in the Palar valley (India). World Development, 27(9): 1673-1692.

Khan, A. (2007) Representing Children: Power, Policy and the Discourse on Child Labour in the Football Manufacturing Industry of Sialkot. Karachi: Oxford University Press.

Locke, R. M., Qin, F., Brause, A. (2007) Does monitoring improve labor standards? Lessons from Nike. Industrial and Labor Relations Review, 61(1): 3-31.

Locke, R. M. and Romis, M. (2007) Improving work conditions in global supply chain. MIT Sloan Management Review, 48(2): 54-62.

Lund-Thomsen, P. (2007) Assessing the impact of public-private partnerships in the Global South: the case of the Kasur tanneries pollution control project. Market, Business and Regulation Programme Paper no. 4, Geneva, United Nations Research Institute for Social Development (UNRSID).

Messner, D. (1997) The Network Society, Economic Development and International Competitiveness as Problems of Social Governance. London: Frank Cass.

Messner, D. (2004) Regions in the 'world economic triangle'. In Schmitz (ed.) Local Enterprises in the Global Economy. Cheltenham: Edward Elgar.

Nadvi, K. (1999) Collective efficiency and collective failure: the response of the Sialkot surgical instrument cluster to global quality pressures. World Development, 27(9): $1605-1626$.

Nadvi, K. (2004) The effect of global standards on local producers: a Pakistani case study. In H. Schmitz (ed.) Local Enterprises in the Global Economy. Cheltenham: Edward Elgar.

Nadvi, K. and Wältring, F. (2004) Making sense of global standards. In H. Schmitz (ed.) Local Enterprises in the Global Economy. Cheltenham: Edward Elgar.

Nielsen, M. E. (2005) The politics of corporate responsibility and child labour in the Bangladeshi garment industry. International Affairs, 81(3): 559-580.

O'Riordan, T. (2000) On corporate social reporting. Environment and Planning A, 26: 533-555.

O'Rourke, D. (2003) Outsourcing regulations: analyzing nongovernmental systems of labor standards and monitoring. Policy Studies Journal, 31(1): 1-30.

Piore, M. and Schrank, A. (2006) Labor inspectors in Latin America. In Critical Solidarity, Newsletter of the American Sociological Association's Section on Labor and Labor Movements, 6(2).

Ponte, S. (2007) Governance in the value chain for South African Wine. Tralac Working Paper No 9 [online]. Available online at: http://www.tralac.org/pdf/20071016_WP09Ponte GovernanceValueChainSA_Wine.pdf [Accessed 20 November 2007]. 
Ponte, S. and Gibbon, P. (2005) Quality standards conventions, and the governance of global value chains. Economy and Society, 34(1): 1-31.

Quadros, R. (2004) Global quality standards and technological upgrading in the Brazilian autocomponents industry. In H. Schmitz (ed.) Local Enterprises in the Global Economy. Cheltenham: Edward Elgar.

Reardon, T., Codron, J.-M., Busch, L., Bingen, J., Harris, C. (2001) Global change in agrifood grades and standards: agribusiness strategic responses in developing countries. International Food and Agribusiness Management Review, 2(3): 421-435.

Reardon, T., Henson, S., Berdegué, J. A. (2007) 'Proactive fast-tracking' diffusion of supermarkets in developing countries: implications for market institutions and trade. Journal of Economic Geography, 7(4): 1-33.

Schrank, A. (2006) Labor inspectors in the CAFTA region: cosmetic, costly or constructive? Available online at: http://www.unc.edu/ mosley/Schrankpaper.pdf [Accessed 14 January 2008].

Seddon, J. (2000) The Case against ISO 9000. Dublin: Oak Tree Press.

Sturgeon, T. (2003) Exploring the risks of value chain modularity: electronics outsourcing during the industry cycle of 1992-2002. IPC Working Paper Series MIT-IPC-O3-002, Industrial Performance Centre, Massachusetts Institute of Technology (MIT), Cambridge Mass.

Tallontire, A., Dolan, C., Smith, S., Barrientos, S. (2005) Reaching the Marginalised? Gender value chains and ethical trade in African horticulture. Development in Practice, 15(3-4): 559-571.

Utting, P. and Zammit, A. (2006) Beyond pragmatism: appraising UN-business partnerships. Market, Business and Regulation Programme Paper no. 1, Geneva, United Nations Research Institute for Social Development (UNRSID).

Zadek, S. (2004) The path to corporate responsibility. Harvard Business Review, 82(12): 125-132. 
Reproduced with permission of the copyright owner. Further reproduction prohibited without permission. 